\title{
Hector Berlioz
}

Author(s): Joseph Bennett

Source: The Musical Times and Singing Class Circular, Vol. 22, No. 466 (Dec. 1, 1881), p. 649

Published by: Musical Times Publications Ltd.

Stable URL: http://www.jstor.org/stable/3358046

Accessed: 25-06-2016 12:18 UTC

Your use of the JSTOR archive indicates your acceptance of the Terms \& Conditions of Use, available at

http://about.jstor.org/terms

JSTOR is a not-for-profit service that helps scholars, researchers, and students discover, use, and build upon a wide range of content in a trusted digital archive. We use information technology and tools to increase productivity and facilitate new forms of scholarship. For more information about JSTOR, please contact support@jstor.org.

Musical Times Publications Ltd. is collaborating with JSTOR to digitize, preserve and extend access to The Musical Times and Singing Class Circular 
for two oboes (Handel); Duetto bouffe from "Truci Amanti" (Cimarosa); Overture, "Carnaval Romain" (Berlioz). Concert Populaire (November 6): Symphony in A major (Haydn); Souvenir de Lisbonne (Saint-Saëns); Dramatic Concerto for violin (Spohr); Symphony in “ minor (Beethoven); Air from "Ariodant" (Méhul); Overture, "Tannhäuser" (Wagner). Châtelet Concert (November 6): "Kisode de la Vie d'un Artiste" (Berlioz). Nouvaux Concerts (November 6) Pastoral Symphony (Beethoven); Air from "Alcina" (Handel); Pianoforte Concerto, A minor (Schumann); Orchestral Rhapsody (Lalo); Introduction and Romance from "La Statue" (E. Reyer); Overture, "Rienzi" (Wagner). Concert Populaire (November I3) Symphony, F major (Beethoven); Prelude to "Lohengrin"(Wagner); Violin "Concerto (Raff); Fragments from "Midsummer Night's Dream" (Mendelssohn); Arioso from "Le Prophète" (Meyerbeer) Overture, "Freischütz" (Weber). Châtelet Concert (November I3) Overture, "Dinorah" (Meyerbeer); "Lelio, ou le Retour à la Vie" (Berlioz); "Le Désert" (F. David). Nouvaux Concerts (November I3): Pastoral Symphony (Beethoven); "La Madeleine au Désert" (Reyer); Orchestral Rhapsody (Lalo); Pianoforte Concerto, A minor (Schumann); Overture, "Rienzi" (Wagner). Concert Populaire (November 20): "La Damnation de Faust" (Berlioz). Châtelet Concert (November 20); Overture, "Tannhäuser "(Wagner); Fragments
from "Tannhäuser" (Wagner); "Le Désert" (F. David). Nouvaux from "Tannhäuser" (Wagner); "Le Désert" (F. David). Nouvaux Concerts (November 20): Symphony in F (Th. Gouvy); "La Madeleine au Désert" (Reyer); Adagio for violoncello (M. Bruch); Overture, "Flying Dutchma

Erinnyes" (Massenet)

Leipzig.-Conservatorium Concert, in memory of Mendelssohn's death (November 4): Pianoforte Trio in C minor; Pianoforte Fantasia, Op. 28 ; Duets for soprano and alto; Capriccio for strings, Op. 8r, No. 9; Pianoforte Quartet in B minor, Op. 3; Rec Chorus, from oratorio "Christus" (Mendelssohn).

Cologne.-Concert-Gesellschaft (October 25): Oratorio, "Saul" (Ferdinand Hiller). Concert-Gesellschaft (November 8): Concert Overture (Taubert); Recitative and Air from "Semele" (Handel); Concertstück for violin, Op. 20 (Saint-Saëns); Violin solos (Holländer, Wieniawski); 98th Psalm (Mendelssohn); Vocal soli (Schubert, Hiller, Brahms). Concert-Gesellschaft (November 22): Symphony in B flat major (Schumann); Air from "La Clemenza di Tito"(Mozart); Pianoforte Concerto in E minor (Chopin); Tragic Overture, (Brahms); Zigeunerleben, for chorus and orchestra (Schumann); Pianoforte pieces (Schubert, Heymann, Liszt); Vocal soli (Schubert, Böttcher).

Baden-Baden.-Symphonie-Concert of Herr Könnemann (November II): Symphony in D (Könnemann); Overture, "Beherrscher der Geister" (Weber); Träumerein, from "Kinderscenen," arranged for string orchestra (Schumann); Danse Macabre (Saint-Saëns). Concert of the Cur-Orchester (November I8): Overture, "Zur Weihe des Hauses" (Beethoven); Violoncello Concerto in D minor(Raff); Sieg-
fried Idyl (Wagner); Pieces for violoncello (P. Martini, Weber); fried Idyl (Wagner); Pieces for violoncello

Symphony, No. I, in B flat major (Schumann).
Boston.-Symphony Orchestra, conducted by G. Henschel (October 22): Overture, "Weihe des Hauses" (Beethoven); Air from "Orpheus" (Gluck); Symphony in B flat (Haydn); Ballet music from "Rosa. munde" (Schubert); Scena from "Odysseus" (Bruch); Jubilee Overture (Weber). Symphony Orchestra (October 29): Tragic Overture (Brahms); Pianoforte Concerto in A minor (E. Grieg); Symphony in C, No. I (Beethoven); Pianoforte solos (Schumann, Chopin); March from Suite, Op. I13 (F. Lachner). Symphony Orchestra (November 5): Tragic Overture (Brahms); Air, "Giulio Cesare" (Handel); Symphony in G minor (Mozart); Slavonian Dances, Op. 46 (Dvorák); Hymne au Créateur (Henschel); Overture, "Merry Wives of Windsor" (Nicolai). Symphony Orchestra (November r2): Overture, "Ruy Blas" (Mendelssohn); Pianoforte Concerto, No. 3 (Rubinstein);
Symphony, No. 2 (Beethoven); Pianoforte solos (Bach, Chopin) Symphony, No. 2 (Beethoven); Pianoforte

Introduction to "Die Meistersinger" (Wagner). 2I): Choral Overture (John A. West); Violin Concerto, Op. 26 (Bruch); Organ Sonata (H. M. Wild); Hymn (Merkel); "Rigoletto" Fantasia (Liszt); Cornet and Organ Fantasia (Hocht); Easter Hymn (Otis) for solo voices, chorus, and organ.

\section{CORRESPONDENCE.}

\section{HECTOR BERLIOZ.}

TO THE EDITOR OF " THE MUSICAL TIMES."

SiR,-Doubtless there are in this country many valuable unpublished letters of Hector Berlioz. Will their owners be good enough to send me copies? Nothing written by such a man should be lost to the public; and as the articles which have appeared in your journal concerning him are about to be printed, with additions, in book form, I am led to make an appeal which I hope is reasonable, and I know is timely.

Io6, Haverstock Hill, N.W. Joseph BenNetT.

\section{A PLEA FOR THE MODERNS.}

TO THE EDITOR OF "THE MUSICAL TIMES."

Sir,-Your allusion, in the article last month on $\mathrm{Dr}$. Stainer's address, to Professor Macfarren's speech has revived my abandoned intention of uttering a protest against the main topic of that speech. As an old and attached former pupil of Professor Macfarren's I cannot but wonder that the experienced and wise guide of my early steps, who used so to commend the great diversity and extent of my musical reading, should be so untrue to his principles as to urge students not to study the modern composers, "for fear of imbibing inartistic or revolutionary ideas." I have made a point of becoming acquainted with as many as possible of our young musicians and music-students, and I find the same fault in them all-their studies have been too narrow and limited. In these days of cheap editions and music libraries there is no excuse for this. Let them devour huge quantities of music, no matter of what kind. Let them make a point of reading through at the piano every new opera, symphony, or quartet that comes out. Let them study Brahms and Barnett, Schumann and Sullivan, Bach and Offenbachin fine, everything and everybody. Thus, and thus only, will they open their minds and, when they arrive at years of discretion, find themselves on a level with contemporary thought, instead of miles behind it, as too many are at present. I suppose the growth of my musical mind was much the same as most people's: let me sketch it. Happily I was not put in leading-strings at too early an age, and was allowed to study what I liked. My first passion was for Weber, and I saturated myself with his operas, masses, songs, and pianoforte works. Mendelssohn had a dose of through my brothers and sisters, and, some kind friend presenting me with a fine edition of his complete pianoforte works, I soon wearied of him. Then I adored Spohr, and, through Augener's library, obtained numerous forgotten works of this worthy. So on to Chopin and Schumann, as my pianistic capabilities developed (in every case nothing but the complete works would satisfy me); and at this period I went to the Academy and horrified my teacher by being unable to quote a single theme from a single symphony of Beethoven's. In fact, up to the age of seventeen, I considered the old masters dull and dry, for the simple reason that, never having earned musical construction, I could not appreciate their beauties. Now a new world was opened to me, and Bach. Mozart, and finally Beethoven, were digested with delight. But at the same time that I was learning to appreciate the First Symphony of Beethoven, I was studying the full scores of "Tristan and Isolde" and the "Ring des Nibelungen." Before I had even got through the "Messiah," I knew Liszt's "St. Elizabeth" and "Graner Messe." Was I any the worse for this? My early compositionsas Professor Macfarren will remember-were extravagant and wild, but better be this than dull and dreary. A few more years of study enabled me to distinguish between corn and husks-enabled me to sift the good from the bad in my plentiful brain-library. I have yet my reputation to make as a composer, hut $I$ have at least the pleasure of knowing that what I write is not behind the age, and consequently that it has a chance of vitality Soyons de notre siècle. In these days, when you go to write an oratorio, for instance, it is not enough to be acquainted with the "Messiah," "Creation," and "Elijah"; you want to know Bach's "Passion," Beethoven's "Mount of Olives," Brahms's " Requiem," Kiel's "Christus," Liszt's "Christus"-in fact, contemporary as well as past specimens. What do our English song-writers know, again? They have heard Sullivan's and Cowen's ballads and a few songs of Schubert; but which of them is acquainted with the numerous and varied productions of Franz, Jensen, Raff, Liszt, and Brahms? I repeat-study every composer and style indiscriminately, and to the greatest possible extent; then, and then only, will you have a chance of writing well and originally.

One more point. Who are the individual composers forming that much-abused but indefinite body, "the Wagnerites," "the apostles of ugliness," "the revolutionary school" as they are variously called ? They seem to me to have about as much real existence as the Esthetes. Critics are for ever abusing them en masse, but when they leave generalities and speak of individual works and writers we hear no more of these epithets. In fact, Brahms, Raft, Goldinark, Dvorák, Bargiel, Rubinstein, who are the only living symphonists of sufficient position to be worth abusing, are all so different from one another that it would be absurd to class any of them together as forming a school ; while, as to revolutionary ideas, I confess I fail to see in any of their works aught but the natural development of Mendelssohn-Schumann lines of thought, with about half 